\title{
Probing the Role of the Chloroplasts in Heavy Metal Tolerance and Accumulation in Euglena gracilis
}

\author{
Bishal Khatiwada ${ }^{1,2} \mathbb{D}^{-}$, Mafruha T. Hasan ${ }^{1,2,+}$, Angela Sun ${ }^{1,2}$, Karthik Shantharam Kamath ${ }^{1,2,3}$, \\ Mehdi Mirzaei 1,2,3, Anwar Sunna 1,2,*(D) and Helena Nevalainen 1,2,* \\ 1 Department of Molecular Sciences, Macquarie University, Sydney, NSW 2109, Australia; \\ bishal.khatiwada@hdr.mq.edu.au (B.K.); mafruha.hasan@sydney.edu.au (M.T.H.); \\ angela.sun@mq.edu.au (A.S.); karthik.kamath@mq.edu.au (K.S.K.); mehdi.mirzaei@mq.edu.au (M.M.) \\ 2 Biomolecular Discovery and Design Research Centre, Macquarie University, Sydney, NSW 2109, Australia \\ 3 Australian Proteome Analysis Facility, Macquarie University, Sydney, NSW 2109, Australia \\ * Correspondence: anwar.sunna@mq.edu.au (A.S.); helena.nevalainen@mq.edu.au (H.N.) \\ + Current address: School of Life and Environmental Sciences, The University of Sydney, Sydney, NSW \\ 2015, Australia.
}

Received: 23 December 2019; Accepted: 12 January 2020; Published: 14 January 2020

\begin{abstract}
The E. gracilis Zm-strain lacking chloroplasts, characterized in this study, was compared with the earlier assessed wild type Z-strain to explore the role of chloroplasts in heavy metal accumulation and tolerance. Comparison of the minimum inhibitory concentration (MIC) values indicated that both strains tolerated similar concentrations of mercury $(\mathrm{Hg})$ and lead $(\mathrm{Pb})$, but cadmium $(\mathrm{Cd})$ tolerance of the Z-strain was twice that of the Zm-strain. The ability of the $\mathrm{Zm}$-strain to accumulate $\mathrm{Hg}$ was higher compared to the Z-strain, indicating the existence of a $\mathrm{Hg}$ transportation and accumulation mechanism not depending on the presence of chloroplasts. Transmission electron microscopy (TEM) showed maximum accumulation of $\mathrm{Hg}$ in the cytosol of the $\mathrm{Zm}$-strain and highest accumulation of $\mathrm{Cd}$ in the chloroplasts of the Z-strain indicating a difference in the ability of the two strains to deposit heavy metals in the cell. The highly abundant heavy metal transporter MTP2 in the Z-strain may have a role in $\mathrm{Cd}$ transportation to the chloroplasts. A multidrug resistance-associated protein highly increased in abundance in the $\mathrm{Zm}$-strain could be a potential $\mathrm{Hg}$ transporter to either cytosol or mitochondria. Overall, the chloroplasts appear to have major role in the tolerance and accumulation of Cd in E. gracilis.
\end{abstract}

Keywords: Euglena gracilis; microalga; heavy metal accumulation; mercury accumulator; transmission electron microscopy (TEM); SWATH-MS

\section{Introduction}

The use of heavy metals in industrial, medical, household, and agricultural products has led to an increase in the deposition and distribution of these metals in the environment arising serious concerns about their impact on living organisms [1,2]. Different approaches such as application of chemicals have been employed to remove heavy metals from the soil and water but most of these have proven inefficient or expensive. Additional problems are generated by large volumes of contaminated sludge requiring further processing [3]. On the other hand, plants, microorganisms, and microalgae have the ability to bioaccumulate heavy metals sustainably, thus reducing the burden imposed on landfill sites and water resources $[4,5]$.

Phytochelatin-mediated heavy metal detoxification has been previously reported in plants, fungi, and algae [6]. In plants, low molecular weight heavy metals are first complexed with phytochelatins (LMW HM-PC), and transported into vacuoles for the later conversion into high molecular weight 
heavy metal-phytochelatin complexes (HMW HM-PC). The same mechanism appears to be functional in yeasts and algae [7-10]. In yeast [11], rice [12], and green algae, mitochondria are also involved in the accumulation of heavy metals [13], where the mitochondrial solute carrier (MSC) family proteins transport solutes and metal ions into the mitochondria [14]. Detoxification of heavy metals in the mitochondria has not reported so far, however, a few studies have indicated that heavy metal accumulation causes metal-induced toxicity and stress in mitochondria $[15,16]$.

Cyanobacteria and photosynthetic green algae have the ability to deposit heavy metals in their chloroplasts [17]. Organisms with chloroplasts have a well-organized cellular machinery for bioaccumulation of metals since some of the cofactors used in the chloroplast electron transfer apparatus, such as iron, copper $(\mathrm{Cu})$ and zinc $(\mathrm{Zn})$ metals are readily available. Following this, toxic heavy metals such as cadmium $(\mathrm{Cd})$, lead $(\mathrm{Pb})$ and mercury $(\mathrm{Hg})$ can mimic essential metals and use their transporters and ion-channels to move inside intracellular organelles [18]. This makes possible the storage of heavy metals inside the chloroplasts; however, if the cells cannot withstand their toxicity, heavy metals are extruded using cellular efflux pumps [19].

In the studies of heavy metal tolerance and accumulation by microalgae such as Chlamydomonas reinhardtii [20], Oedogonium westii [21] and marine algae [22], bioaccumulation of heavy metals has been mostly observed in the vacuoles $[23,24]$. E. gracilis studied here has the capacity to uptake metals such as $\mathrm{Cd}, \mathrm{Pb}$ and $\mathrm{Hg}$ [24,25] but lacks a proper vacuole found in plants and fungi [26]. Therefore, in the absence of vacuoles, E. gracilis might use either the cytoplasm or cellular structures such as chloroplasts and mitochondria to accumulate heavy metals. In a previous study conducted with E. gracilis to investigate $\mathrm{Cu}$ and $\mathrm{Zn}$ accumulation, the results indicated that $\mathrm{Cu}$ affected chloroplast organization and metal accumulation was observed inside the contractile vacuole, as indicated by the vacuolar structure. Heavy metals were also distributed into the chloroplasts and cytoplasm [27].

This study was conducted to explore the role of chloroplasts in the accumulation of heavy metals $(\mathrm{Cd}, \mathrm{Hg}$ and $\mathrm{Pb})$ in E. gracilis. The MIC and the maximum ability to accumulate heavy metals were compared between the previously assessed wild-type Z-strain [28] that can develop mature chloroplasts and a variant strain $(\mathrm{Zm})$ that was unable to develop chloroplasts. Sequential window acquisition of all theoretical fragment-ion spectra- mass spectrometry (SWATH-MS) was performed to analyze differences in the proteomes between the two strains. The relative abundance of proteins was compared to identify the proteins involved in heavy metal bioaccumulation. Deposition of the heavy metals inside the cells was established using transmission electron microscopy.

\section{Materials and Method}

\subsection{Chemicals}

All chemicals and reagents were purchased from Sigma Aldrich (Castle Hill, NSW, Australia) unless stated otherwise.

\subsection{Algal Strains and Culture Conditions}

The Euglena gracilis Z-strain (UTEX 753) was obtained from the University of Texas Culture Collection, Austin, TX, USA. A stable non-chloroplast variant Euglena gracilis Zm-strain was developed in-house by supplementing the cultivation medium with streptomycin for several generations; this culture has been maintained over two years. The absence of chloroplasts in the $\mathrm{Zm}$-strain was confirmed by the means of a fluorescence microscope, Olympus BX51, using the blue excitation filter (excitation $=480 / 20$, emission $=510 \mathrm{LP})$.

Both strains were grown mixotrophically in a glucose, ammonium chloride and yeast extract (GNY) medium (modified Hutner medium; $\mathrm{pH}$ 3.5) [29] at $23^{\circ} \mathrm{C}$ with orbital shaking at $150 \mathrm{rpm}$. The heavy metals mercury $\left(\mathrm{HgCl}_{2}\right)$, lead $\left(\mathrm{Pb}\left(\mathrm{NO}_{3}\right)_{2}\right)$ and cadmium $\left(\mathrm{CdCl}_{2}\right)$ were mixed with the GNY medium in varying concentrations for determination of the minimum inhibitory concentration (MIC) for the 
$\mathrm{Zm}$-strain. The stock solution of heavy metals was prepared in sterile double distilled water $\left(\mathrm{ddH}_{2} \mathrm{O}\right)$ and sterilized using a 0.2-micron filter. All experiments were conducted using biological triplicates.

\subsection{Minimum Inhibitory Concentration (MIC) Assay}

The ability of the E. gracilis Zm-strain to withstand heavy metal exposure was determined by the MIC assay as previously described [28]. Briefly, the cultures were subjected to different concentrations of metal: $\mathrm{Hg}$ (5-90 ppm), Pb (500-10,000 ppm) and Cd (50-1000 ppm). Cells were counted using a hemocytometer during cultivation. The cell count of cultures treated with heavy metals was compared with that of the untreated cultures, assigned as $100 \%$.

\subsection{Determination of Heavy Metal Bioaccumulation}

The maximum capacity of the E. gracilis $\mathrm{Zm}$ - strain to bioaccumulate heavy metals was determined using microwave plasma atomic emission spectroscopy (4100 MP-AES, Agilent, USA). Cells were grown in a GNY medium [29] supplemented with either $\mathrm{Cd}(200 \mathrm{ppm}), \mathrm{Pb}$ (500 ppm) and $\mathrm{Hg}$ (50 ppm), selected from the MIC study. Samples were collected at different time points (day 2, 4, 6 and 7) of cultivation and heavy metal accumulation was determined as described previously [28].

\subsection{Transmission Electron Microscopy (TEM)}

Both the Z- and Zm- strains grown in a GNY medium supplemented with a particular heavy metal and controls without heavy metal addition were harvested at the log phase by centrifugation $(500 \times g$; $2 \mathrm{~min}$ ) and washed twice with $\mathrm{ddH}_{2} \mathrm{O}$. All chemicals used in TEM were purchased from ProSciTech, Australia. Primary fixation of the cells was performed using 2.5\% $(v / v)$ glutaraldehyde and $2.5 \%(v / v)$ paraformaldehyde for $2 \mathrm{~h}$ and secondary fixation was carried out using $2 \%(v / v)$ osmium tetroxide $\left(\mathrm{OsO}_{4}\right)$ for $1.5 \mathrm{~h}$. The cells were dehydrated with graded ethanol solutions $(50 \%, 70 \%, 90 \%, 95 \%, 100 \%$ $v / v)$. After this, the cells were infiltrated with increasing concentrations of London resin (LR) white resin medium grade at 50\%,75\% and finally 100\% $(v / v)$. Infiltration was carried out for $2 \mathrm{~h}$ for each concentration of LR white resin except the $100 \%$ LR white resin, for which the cells were incubated at RT (room temperature) overnight on a rotator. On the following day, the resin was replaced with fresh $100 \% \mathrm{LR}$ white resin and the cells were incubated at RT for $3 \mathrm{~h}$. The samples were then allowed to polymerize inside an oven at $60^{\circ} \mathrm{C}$ for $48 \mathrm{~h}$.

Ultrathin resin sections were prepared on Ultramicrotome Leica EM UC7 and the sections were stained serially with uranyl acetate and lead citrate. The sections were then studied on a Philips CM10 Transmission Electron Microscope. Control cells without metal treatment were compared against heavy metal treated samples to identify the location of heavy metal accumulation.

\subsection{Extraction of Proteins and Peptides}

Aliquots of the E. gracilis Zm-strain cultures grown with each heavy metal were collected at the maximum heavy metal accumulation time points as determined by MP-AES (Section 3.2) and proteins and peptides were extracted as described earlier for the Z-strain [28]. All experiments were carried out in biological triplicates.

\subsection{Mass Spectrometry Analysis}

A TripleTOF 5600 mass spectrometer was used to analyze the peptides from the proteins extracted from the Zm-strain treated with heavy metals. All experiments were carried out in biological triplicates (Figure 1). The SWATH experiment was carried out in two-steps: information-dependent acquisition-mass spectrometry (IDA-MS) was used to generate the ion library and SWATH-MS was applied for label-free quantification (Figure 1). 


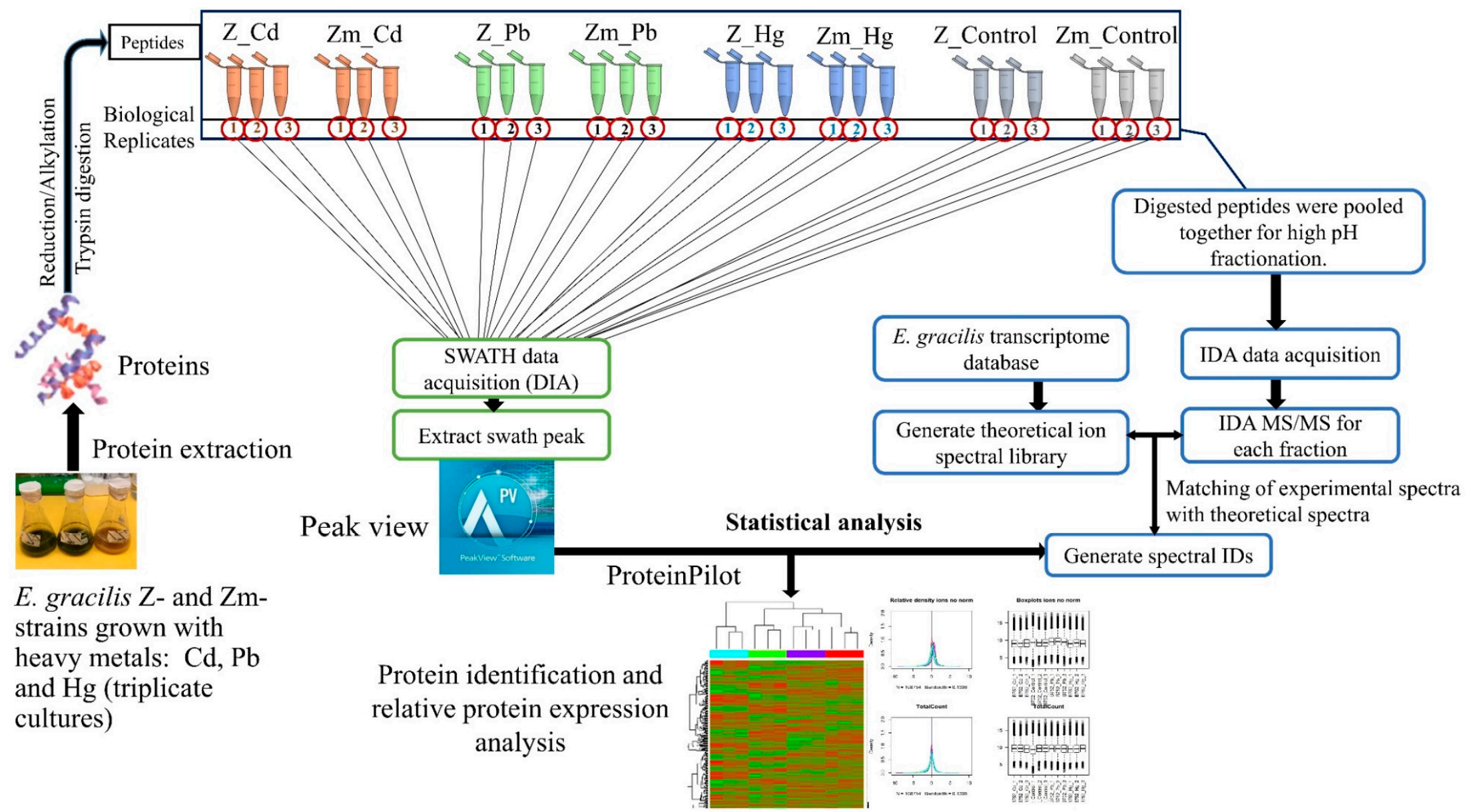

Figure 1. Workflow of SWATH-MS. The empirical ion/spectral library was generated by IDA-MS. SWATH acquisition enabled comparison of the spectra to the spectral library and label-free relative quantification of proteins. The relative abundance of proteins was compared between heavy metal treated and untreated control samples. Statistical analysis was performed as stated in Section 2.9. 


\subsection{Creation of a Peptide Ion Library (IDA-MS)}

Extracted peptides were fractionated with modifications as described [28]. The generated ion library was searched against the Euglena non-redundant protein database available at the John Innes Centre website (http://jicbio.nbi.ac.uk/euglena/), acquired in September 2016. In the search parameter, carbamidomethylation of cysteine residues was used as a fixed modification. Candidate proteins were identified using the following criteria: Unused Score $>2$ (signifying $99 \%$ confidence level) and global peptide false discovery rate (FDR) $<1 \%$.

\subsection{SWATH-MS Data Processing and Statistical Analysis}

SWATH mass spectrometry and data processing were performed as described previously [28]. A complete SWATH-MS workflow is presented in Figure 1. Peptide extraction, SWATH-MS, and data processing have been carried out with the Z-strain previously [28] and were used here for comparison with the corresponding data obtained from the $\mathrm{Zm}$-strain in this study. Proteins with relative expression fold-changes of \pm 1.5 and $p$-value $<0.05$ were considered statistically significantly altered in expression between respective conditions. Proteomic survey will reveal the proteins involved in heavy metal tolerance and accumulation and the role of chloroplasts and chloroplast-related proteins in heavy metal sequestration and transportation into chloroplasts.

\subsection{Functional Annotation}

The Blast2GO software was used to annotate the proteins [28]. Sequences obtained from the Euglena non-redundant proteins database were matched with the UniProtKB/Swiss-Prot database with an $E$-value cut-off of $1 \mathrm{e}^{-10}$. Gene Ontology (GO) information of proteins was derived using the UniProt database.

\section{Results and Discussion}

\subsection{Fluorescence Microscopy of the E. gracilis Strains}

The loss of chloroplasts in the $\mathrm{Zm}$-strain was confirmed with fluorescence microscopy (Figure 2) and further by TEM (Section 3.3). The wild type Z-strain had a bright red fluorescence brought about by the chlorophyll in the chloroplasts, however, the Zm-strain lacked the red fluorescence (Figure 2). Streptomycin treatment can eliminate chloroplasts from Euglena without significantly inhibiting cell division or the viability of the cells $[30,31]$.

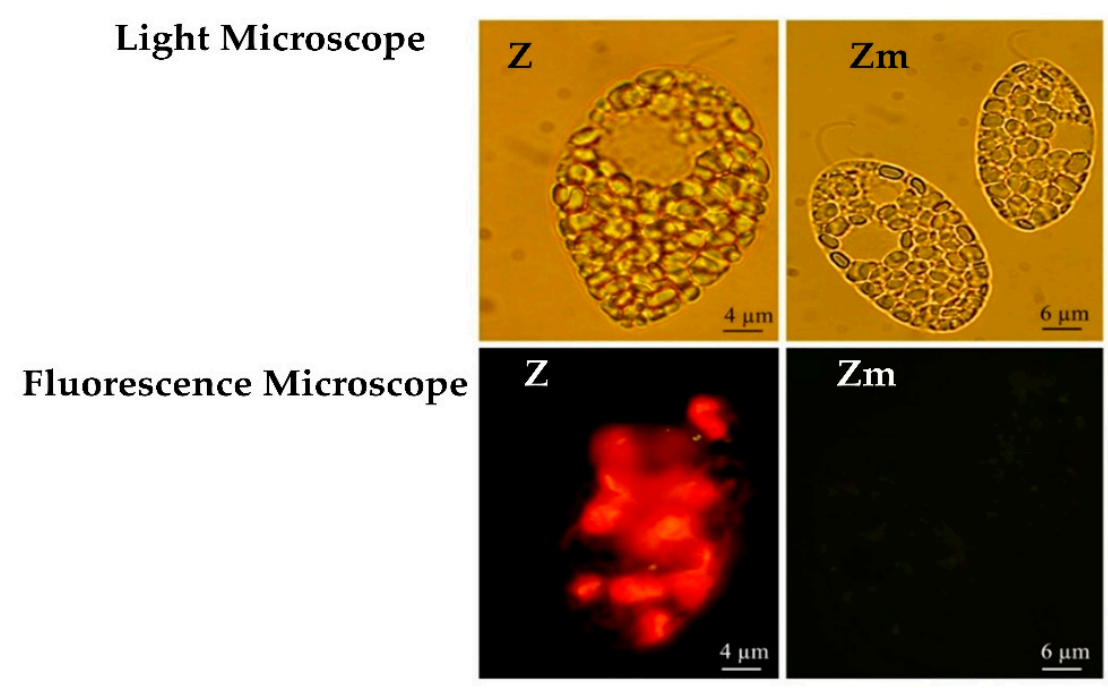

Figure 2. E. gracilis strains visualized under the light microscope and fluorescence microscope. Red fluorescence from the chlorophyll in the chloroplasts appears only in the Z-strain. 


\subsection{Minimum Inhibitory Concentration (MIC)}

The MIC of the three heavy metals for the Zm-strain varied considerably. The lowest MIC (90 ppm) was observed with $\mathrm{Hg}$, which, however is higher than the $\mathrm{Hg}$ MIC of $20 \mathrm{ppm}$ assigned for the freshwater microalgae Phormidium ambiguum, Pseudochlorococcum typicum and Scenedesmus quadricauda var quadrispina [32]. Hg tolerance of $71 \mathrm{ppm}$ has been recorded for brown algae [33]. Although the E. gracilis Zm-strain lacking chloroplasts had a slightly higher $\mathrm{Hg}$ tolerance when compared to that of the Z-strain (80 ppm) [28], the relatively small difference and non-existing information available for other algae do not allow drawing sound conclusions for the possible role of the chloroplasts in $\mathrm{Hg}$ tolerance in algae. The MICs of the Z-strain [28] and Zm-strain (Figure 3) were brought about by the difference in the cellular ability of the strains to withstand the toxicity of each heavy metal since the growth rates between the untreated Z- and Zm- strains were not significantly different $(p>0.05)$ (Supplementary Figure S1).
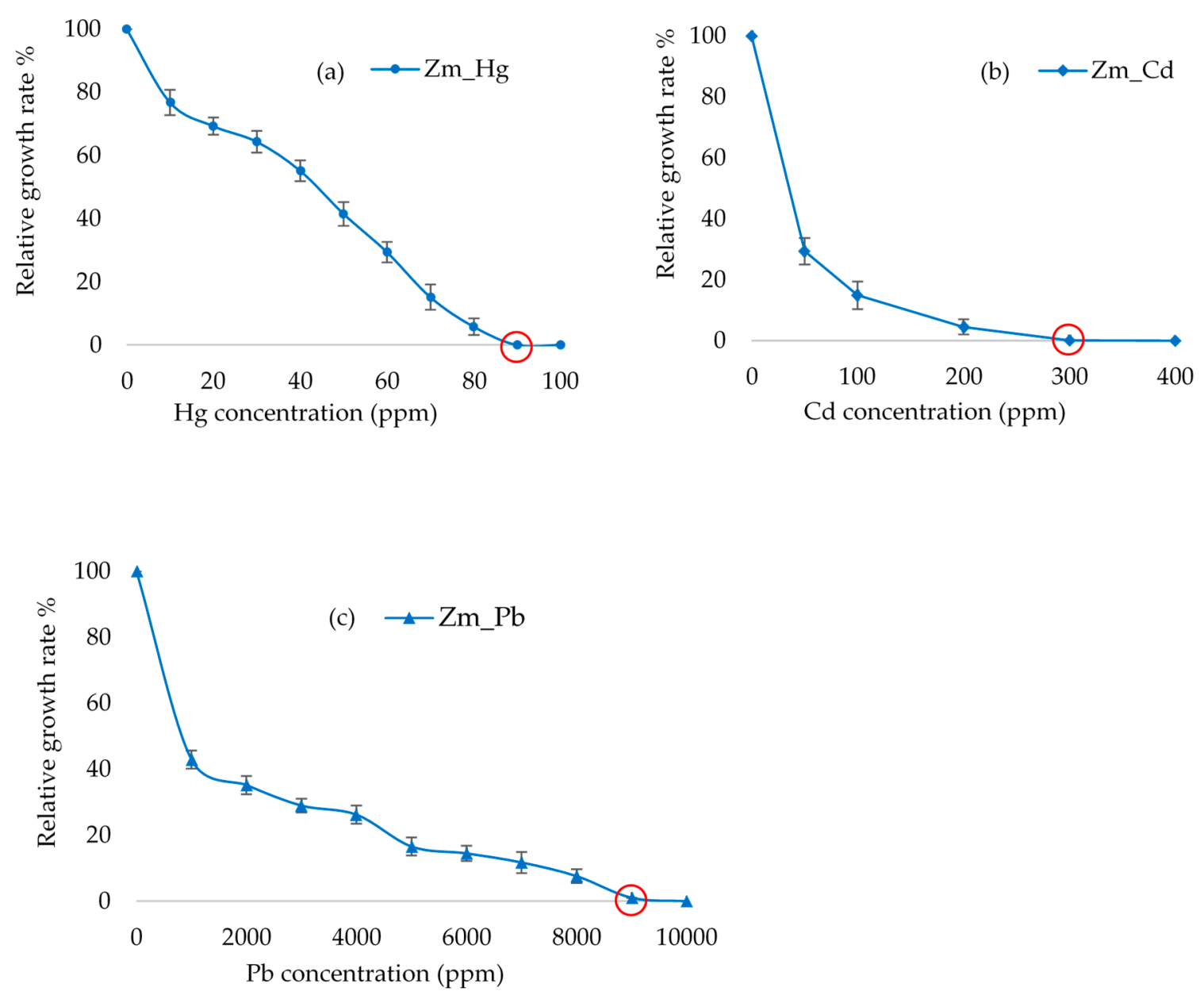

Figure 3. The effect of heavy metals $\mathrm{Hg}(\mathbf{a}), \mathrm{Cd}(\mathbf{b})$ and $\mathrm{Pb}(\mathbf{c})$ on the growth of the E. gracilis $\mathrm{Zm}$ strain. The graph shows the relative growth of cells against a varying concentration of heavy metals. Error bars represent the standard deviation calculated from biological triplicate samples. Minimum inhibitory concentration (MIC) is indicated by the red circle.

The MIC for $\mathrm{Pb}$ in the $\mathrm{Zm}$-strain was $9000 \mathrm{ppm}$, which is about the same as that of the Z-strain from our previous study [28]. Thus, similarly to $\mathrm{Hg}$ tolerance, chloroplasts may not be involved in the tolerance to $\mathrm{Pb}$. Differently to the about similar $\mathrm{Hg}$ and $\mathrm{Pb}$ MIC values established for the two strains, the MIC for Cd with the Zm-strain lacking chloroplasts was $300 \mathrm{ppm}$, which is about half of the $600 \mathrm{ppm}$ determined earlier for the Z-strain containing chloroplasts [28]. A lower tolerance to Cd in the $\mathrm{Zm}$-strain lacking chloroplasts may indicate a role for these organelles in Cd tolerance in Euglena. 


\subsection{Evaluation of the Heavy Metal Accumulation}

MP-AES analysis of the Zm-strain showed that it could accumulate $\mathrm{Hg}$ in higher amounts, $6.54 \mathrm{mg} / \mathrm{g}$ dry weight (DW) at day 2 compared to $\mathrm{Cd}$ and $\mathrm{Pb}$. The maximum $\mathrm{Cd}$ accumulation was recorded on day $6(4.14 \mathrm{mg} / \mathrm{g} \mathrm{DW})$ while only $1.93 \mathrm{mg} / \mathrm{g}$ DW accumulation of $\mathrm{Pb}$ was observed on day 4 .

Although $\mathrm{Hg}$ is more toxic than $\mathrm{Cd}$ and $\mathrm{Pb}$, the order of heavy metal bioaccumulation by the $\mathrm{Zm}$-strain was $\mathrm{Hg}>\mathrm{Cd}>\mathrm{Pb}$ (Figure 4). This suggests that the $\mathrm{Zm}$-strain has an ability to sequester $\mathrm{Hg}$ into a non-toxic form even in the absence of chloroplasts. In our previous study, the average $\mathrm{Hg}$ accumulation from day 2 to day 7 by the wild type Z-strain was $3.77 \mathrm{mg} / \mathrm{g}$ (DW) [28], which is comparatively lower than that of the Zm-strain $(5.84 \mathrm{mg} / \mathrm{g}$, DW) under similar conditions.

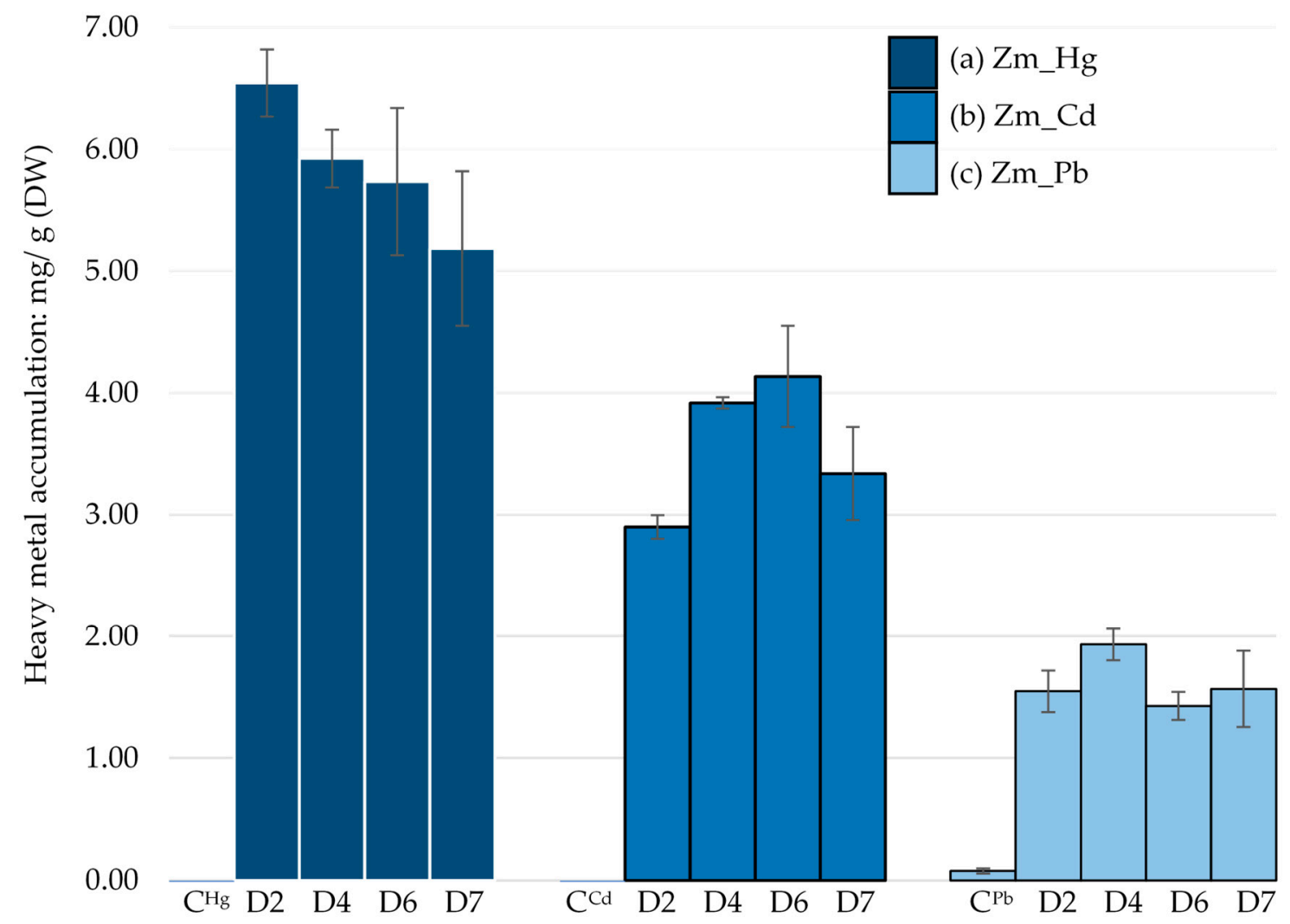

Figure 4. E. gracilis $\mathrm{Zm}$-strain treated with different heavy metals: $(\mathbf{a}) \mathrm{Hg}$, (b) $\mathrm{Cd}$ and (c) $\mathrm{Pb} . \mathrm{C}^{\mathrm{Hg}}, \mathrm{C}^{\mathrm{Cd}}$ and $\mathrm{C}^{\mathrm{Pb}}$ were untreated controls. Heavy metal accumulation per gram of dry weight of each sample was measured between day 2 and 7 by MP-AES. Error bars represent the standard deviation calculated from the biological triplicate samples.

The average $\mathrm{Cd}$ accumulation by the $\mathrm{Zm}$-strain was $3.5 \mathrm{mg} / \mathrm{g}$ (DW), which is lower than in the Z-strain (5.23 mg/g of DW) [28]. This suggests that chloroplasts may contribute to Cd bioaccumulation. $\mathrm{Cd}$ accumulation in the chloroplasts has been reported for Hordeum vulgare, Zea mays [34] and a few other plants [35]. Although some studies are currently underway to understand the role of chloroplasts in $\mathrm{Cd}$ accumulation, most studies have been dedicated to reveal the effects of $\mathrm{Cd}$ toxicity on inhibition of photosynthesis $[36,37]$.

The least amount of heavy metal accumulation by the $\mathrm{Zm}$-strain was for $\mathrm{Pb}$, which remained almost constant between day 2 and 7. MIC results indicated that $\mathrm{Pb}$ was also the least toxic of the three metals tested (Figure 4). The average $\mathrm{Pb}$ bioaccumulation was $1.62 \mathrm{mg} / \mathrm{g}$ (DW), which is similar to the $1.82 \mathrm{mg} / \mathrm{g}$ (DW) by the Z-strain [28]. As the difference between the accumulation of $\mathrm{Pb}$ by chloroplast and non-chloroplast-containing strains was not significant, chloroplasts may not greatly 
contribute to $\mathrm{Pb}$ bioaccumulation. Despite its lower toxicity, $\mathrm{Pb}$ has been reported to cause inhibition of the photosystem in plants, leading to swollen and deformed chloroplasts [38,39]. In the alga Chara vulgaris, $\mathrm{Pb}$ impaired the membrane system of chloroplasts and destroyed the thylakoid structure [40]. However, $\mathrm{Pb}$ does not appear to impair the chloroplasts of E. gracilis (Figure $5 \mathrm{~g}$ ).

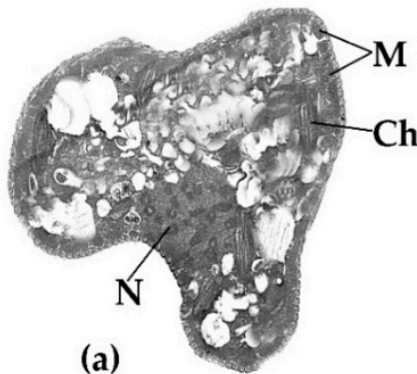

(a)

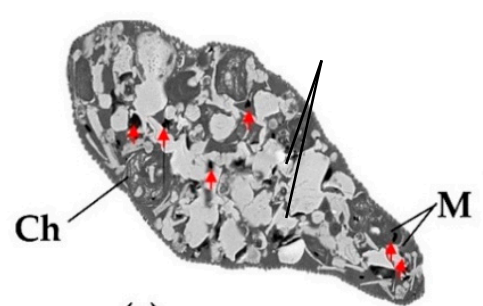

(c)

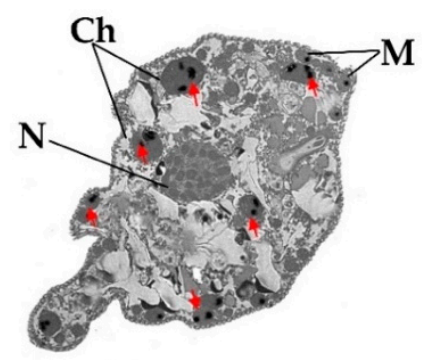

(e)

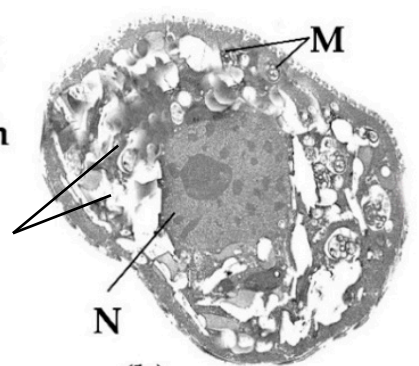

(b)

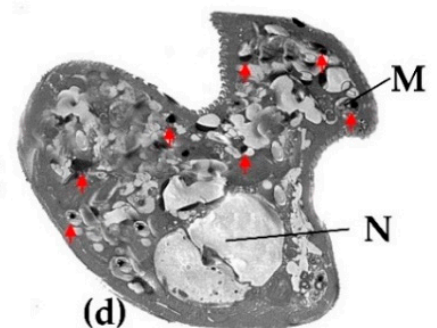

(d)

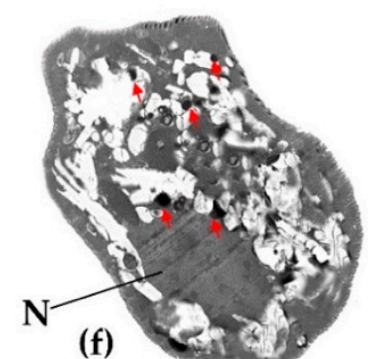

(f)

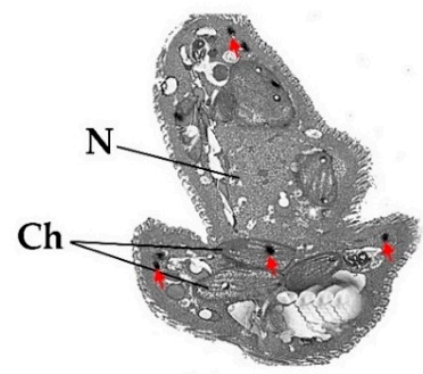

(g)

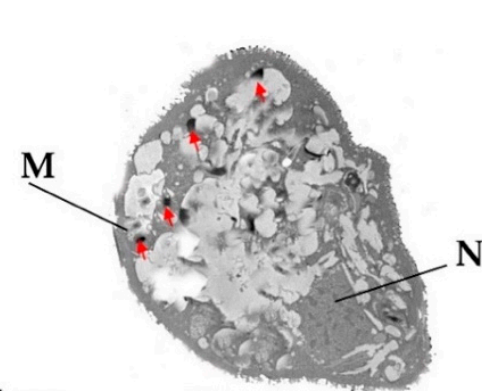

(h)

Figure 5. Visualization of heavy metal accumulation in E. gracilis strains using transmission electron microscope (TEM). (a) Z-strain control- untreated cell; (b) Zm-strain control- untreated cell; (c): Z-strain exposed to $\mathrm{Hg}$; (d): Zm-strain exposed to $\mathrm{Hg}$; (e): Z-strain exposed to Cd; (f): Zm-strain exposed to Cd; (g): Z-strain exposed to $\mathrm{Pb}$; (h): Zm-strain exposed to $\mathrm{Pb}$. P: Paramylon; N; nucleus, M; mitochondria, $\mathrm{Ch}$; chloroplast. Black dots represent heavy metal inclusion and are marked by a red arrow. The $4 \mu \mathrm{m}$ bar corresponds to all images. 


\subsection{Visualization of Heavy Metal Bioaccumulation}

TEM was used to locate heavy metal bioaccumulation in different cellular organelles in the two E. gracilis strains. Treated cells were compared against control cells without heavy metal treatment. Ultrathin sections revealed the internal structure of the cell more clearly in the control cells, while those treated with heavy metals seemed to have lost some cellular integrity. TEM images in Figure 5 show recognizable cellular structures such as nuclei $(\mathrm{N})$, mitochondria $(\mathrm{M})$ and chloroplasts $(\mathrm{Ch})$, and the "ridges and grooves" pattern of the pellicle (cell wall). As expected, there were no chloroplasts in the Zm-strain. The accumulated heavy metals appeared as small black dots while aggregated paramylon granules appeared as white round and oval structures. Euglena does not have a designated reservoir organelle similar to vacuoles in plants [41].

The chloroplasts of E. gracilis are generally spindle-shaped [42]. In the Z-strain treated with $\mathrm{Pb}$, the long spindle-shaped chloroplasts were clearly visible (Figure 5g) while most of the chloroplast structures were damaged in the Hg-treated Z-strain cells, probably because of its toxicity (Figure 5c). The shape of the chloroplasts in the Cd-treated cells of the Z-strain were affected (not spindle shape), probably due to $\mathrm{Cd}$ bioaccumulation and toxicity (Figure 5e). The Zm-strain lacked visible chloroplasts.

In the Z-strain, accumulation of $\mathrm{Hg}$ took place in the cytosol and mitochondria (Figure 5c); a similar deposition pattern was also observed for the Zm-strain (Figure 5d). However, it appears that the number of black dots representing $\mathrm{Hg}$ accumulation was higher in the Zm-strain than in the Z-strain. This result correlates with the fact that the Zm-strain was able to accumulate more $\mathrm{Hg}$ compared to the Z-strain (Figure 4) [28]. This also suggests that chloroplasts do not play a major role in $\mathrm{Hg}$ accumulation or the chloroplasts in the Z-strain were damaged by $\mathrm{Hg}$ resulting in a decrease in their ability to take up the metal. Damage to the chloroplast by mercury has been reported previously in plants and the green alga Chara vulgaris $[40,43]$.

$\mathrm{Cd}$ accumulation mostly occurred in the chloroplasts in the Z-strain, although Cd accumulation was also found in the cytosol and mitochondria (Figure 5e). In the Zm-strain, Cd deposition was seen mostly in the cytosol (Figure 5f). The Z-strain accumulated more Cd than the Zm-strain which suggests that chloroplasts may have a role in $\mathrm{Cd}$ accumulation in the Z-strain. The maximum bioaccumulation was observed during $\mathrm{Cd}$ treatment of the Z-strain, suggesting an established mechanism to sequester large amounts of $\mathrm{Cd}$ in the chloroplasts, rendering this strain a Cd hyperaccumulator [28].

$\mathrm{Pb}$ accumulation was the least among the heavy metals studied here and is consistent with $\mathrm{Pb}$ accumulation shown in Figure 4. $\mathrm{Pb}$ accumulation was distributed fairly evenly in the chloroplasts and cytosol of the Z-strain (Figure $5 \mathrm{~g}$ ). The $\mathrm{Zm}$-strain was found to accumulate $\mathrm{Pb}$ in the cytosol and mitochondria. $\mathrm{Pb}$ accumulation may have been assisted by chloroplasts in the Z-strain, as some black dots were observed in these organelles although both the Z- and Zm-strains had an almost similar ability to accumulate $\mathrm{Pb}$. Chloroplasts seem to be intact and not deformed by $\mathrm{Pb}$ compared to the negative effect of $\mathrm{Hg}$, which highlights the different effects of these heavy metals on cellular organelles of E. gracilis.

The preliminary data obtained from MIC studies, metal accumulation and heavy metal localization revealed differences in the ability and mode of the two strains to handle $\mathrm{Hg}, \mathrm{Pb}$, and $\mathrm{Cd}$.

\subsection{Proteome Profiling of Zm-Strain in Response to Heavy Metals Using SWATH-MS}

Differentially abundant proteins during heavy metal treatment provide a basis to understand the molecular mechanism of heavy metal tolerance and bioaccumulation. The differentially abundant proteins in the Zm-strain exposed to heavy metals were compared to the control without heavy metal exposure. The differentially abundant proteins of the previously assessed Z-strain [28] and the Zmstrain identified in this study were also compared. Through a SWATH-MS analysis, a total of 5325 proteins with FDR $<1 \%$ were identified across the strains and heavy metal treatments, and 4493 proteins were quantified.

Proteome profile of the E. gracilis Zm-strain was significantly changed after exposure to the heavy metals $\mathrm{Cd}, \mathrm{Pb}$ and $\mathrm{Hg}$ when compared to the untreated control of the same strain (Table 1). 
Table 1. Summary of proteins identified from E. gracilis Zm-strain. Triplicates were used for all experiments.

\begin{tabular}{cccc}
\hline Heavy Metal Exposure & $\begin{array}{c}\text { Differentially } \\
\text { Abundant Proteins * }\end{array}$ & $\begin{array}{c}\text { Increased in } \\
\text { Abundance }(\mathbf{1} \mathbf{1 . 5} \text { FC } *)\end{array}$ & $\begin{array}{c}\text { Decreased in } \\
\text { Abundance }(<\mathbf{1 . 5} \text { FC *) }\end{array}$ \\
\hline $\mathbf{H g}$ & 141 & 63 & 78 \\
$\mathbf{C d}$ & 100 & 64 & 36 \\
$\mathbf{P b}$ & 143 & 51 & 92 \\
\hline
\end{tabular}

* (FC) Fold change $\pm 1.5, t$-test $p$-value $<0.05$.

The number of differentially abundant proteins in the Hg-treated Zm-strain was 141, which is higher than the Z-strain (76 proteins) [1]. Despite the high level of toxicity of Hg compared to the other two heavy metals, the Zm-strain was able to accumulate large quantities of $\mathrm{Hg}(5.84 \mathrm{mg} / \mathrm{g}$, DW). A larger number of differentially abundant proteins resulting from $\mathrm{Hg}$ exposure indicated a substantial involvement of proteins to either defend the $\mathrm{Hg}$ toxicity or regulate the cellular machinery to accumulate it for further detoxification. During the $\mathrm{Cd}$ treatment, 960 proteins were increased in abundance $(F C>1.5)$ in the Z-strain [28], compared to just 100 proteins in the Zm-strain. This vast difference in the number of differentially abundant proteins indicates that the chloroplasts in the Z-strain may play a major role in $\mathrm{Cd}$ accumulation and detoxification. $\mathrm{Cd}$ accumulation by the Z-strain was the highest among the heavy metals studied here and was also higher than that of the Zm-strain. $\mathrm{Pb}$ exposure returned a similar number of differentially abundant proteins for both strains, which is reflective of the similar MIC and accumulation patterns (Figure 6).

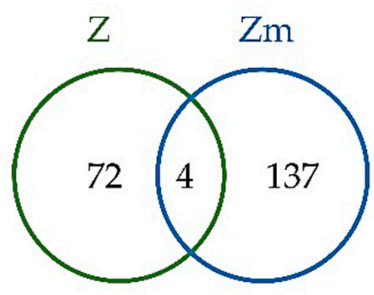

(a)

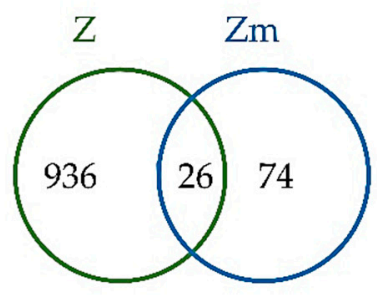

(b)

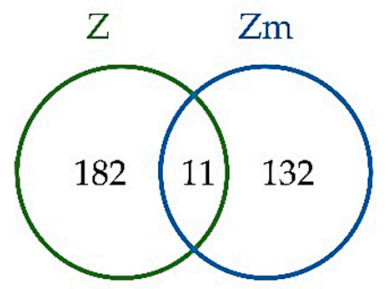

(c)

Figure 6. Venn diagram comparing the differentially abundant proteins between E. gracilis Z-and $\mathrm{Zm}$-strains when treated with the heavy metal $\mathrm{Hg}(\mathbf{a}), \mathrm{Cd}(\mathbf{b})$, and $\mathrm{Pb}(\mathbf{c})$. The intersection of the sets represents the differentially abundant proteins common to both strains for the respective heavy metal treatment.

The differentially abundant proteins between the two strains were compared to identify whether common or unique proteins were involved in heavy metal tolerance and accumulation (Figure 6).

Among the 213 differentially abundant proteins during $\mathrm{Hg}$ treatment, only 4 proteins $(1.87 \%)$ were common to both strains, while for the $\mathrm{Cd}$ and $\mathrm{Pb}$ treatments 26 proteins $(2.51 \%)$ and 11 proteins (3.38 \%) out of a total of 1034 and 325 differentially abundant proteins were common, respectively. This small percentage of common differentially abundant proteins between the strains suggests that strains with and without chloroplasts have different mechanisms for heavy metal tolerance and accumulation. The complete list of differentially abundant proteins common to both strains is shown in Supplementary Table S1.

\subsubsection{Gene Ontology (GO) Annotation}

The differentially abundant proteins from the $\mathrm{Hg}, \mathrm{Cd}$ and $\mathrm{Pb}$ treatments were categorized by their GO annotations using the UniProt database and plotted collectively (Figure 7). 


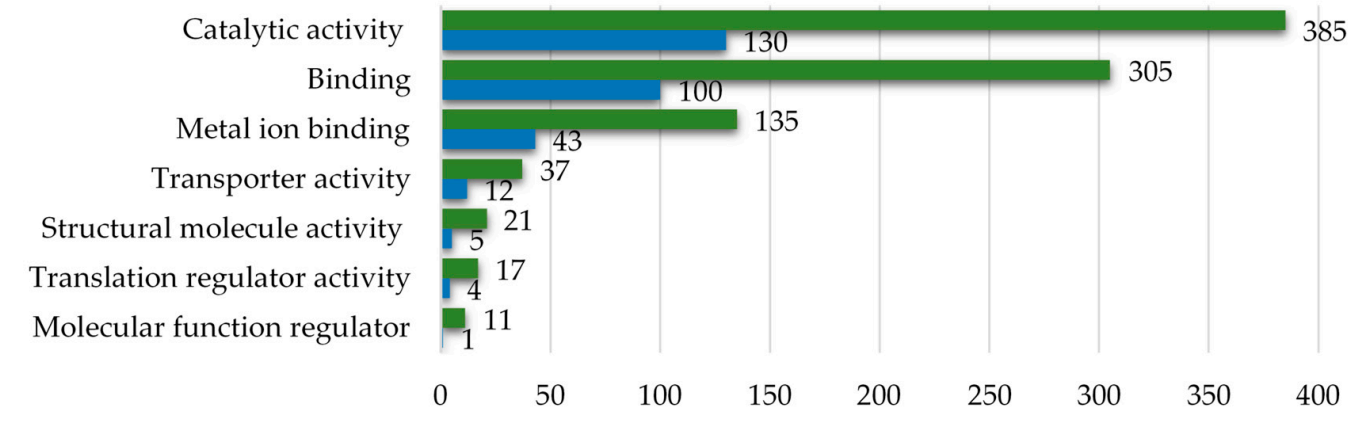

(a) Molecular Function $\quad$ Z-strain $\quad$ Zm-strain
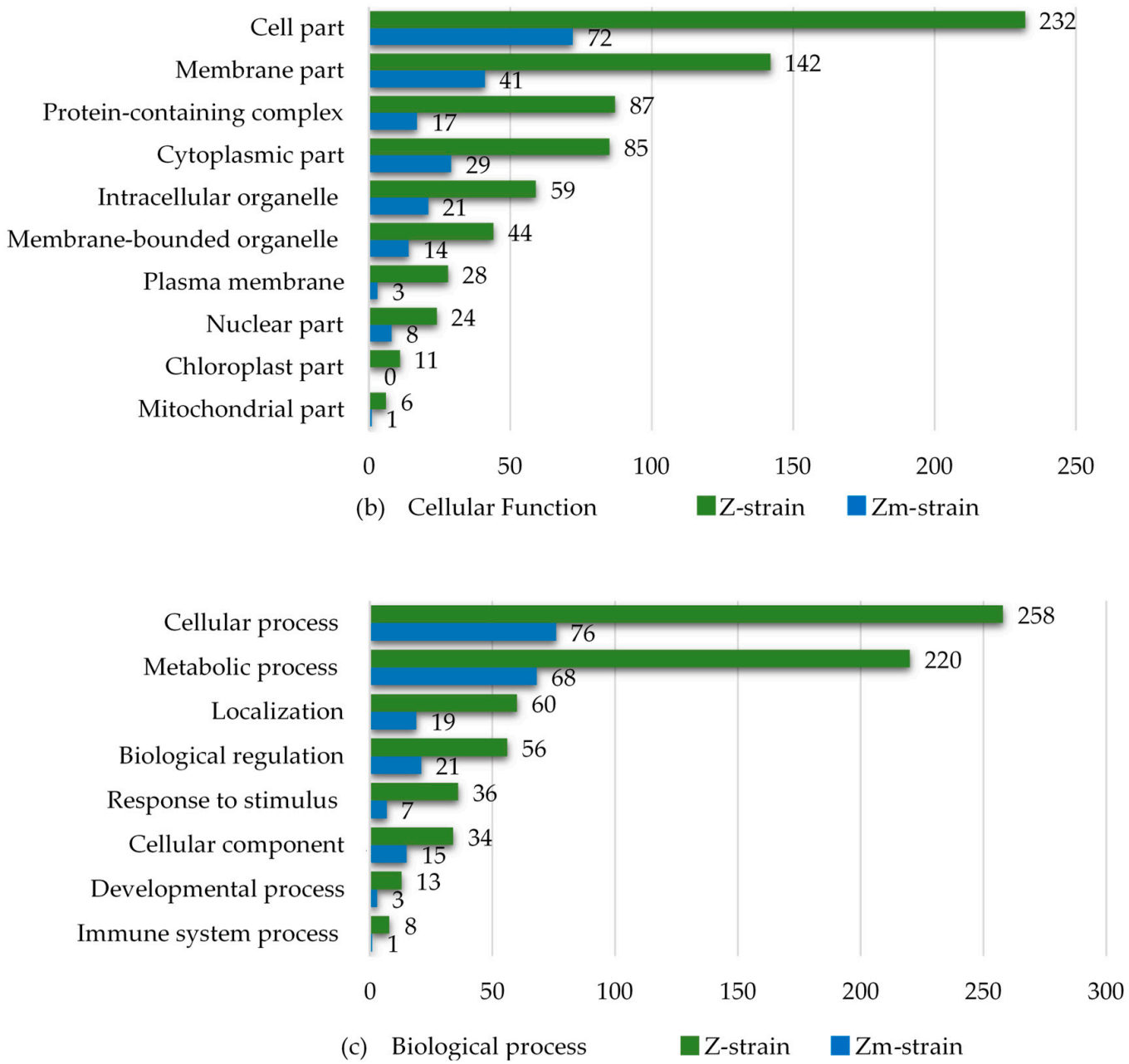

Figure 7. Gene Ontology (GO) annotation of the differentially abundant proteins of the E. gracilis Zand $\mathrm{Zm}$ - strains treated with the heavy metal $\mathrm{Cd}, \mathrm{Hg}$, and $\mathrm{Pb}$ (one metal at a time). The results were collated into three sets: (a) Molecular function, (b) Cellular component and (c) Biological process.

The number of differentially abundant proteins in the categories of "metal ion binding" and "transporter activity" were about three times higher in the Z-strain compared to the Zm-strain. The results also revealed that in all subcategories of the set "Cellular components", the Z-strain showed an extensive response towards heavy metal exposure. The Z-strain appeared metabolically very active, most probably because of the presence of chloroplasts and performing photosynthesis. The number of differentially abundant proteins in the Z-strain were higher in both the cytosol and intracellular organelles. As expected, no chloroplast-related proteins were found in the Zm-strain. In the set 
"Biological process", the Z-strain was more responsive in the subcategories of "cellular" and "metabolic process" during exposure to heavy metals. This suggests that the Z-strain was more reactive towards external stimuli, such as heavy metal toxicity, producing stress responses during exposure. To further understand the ability of the strains to cope with metal toxicity, the proteins increased in abundance in each type of metal treatment were compared (Figure 8).

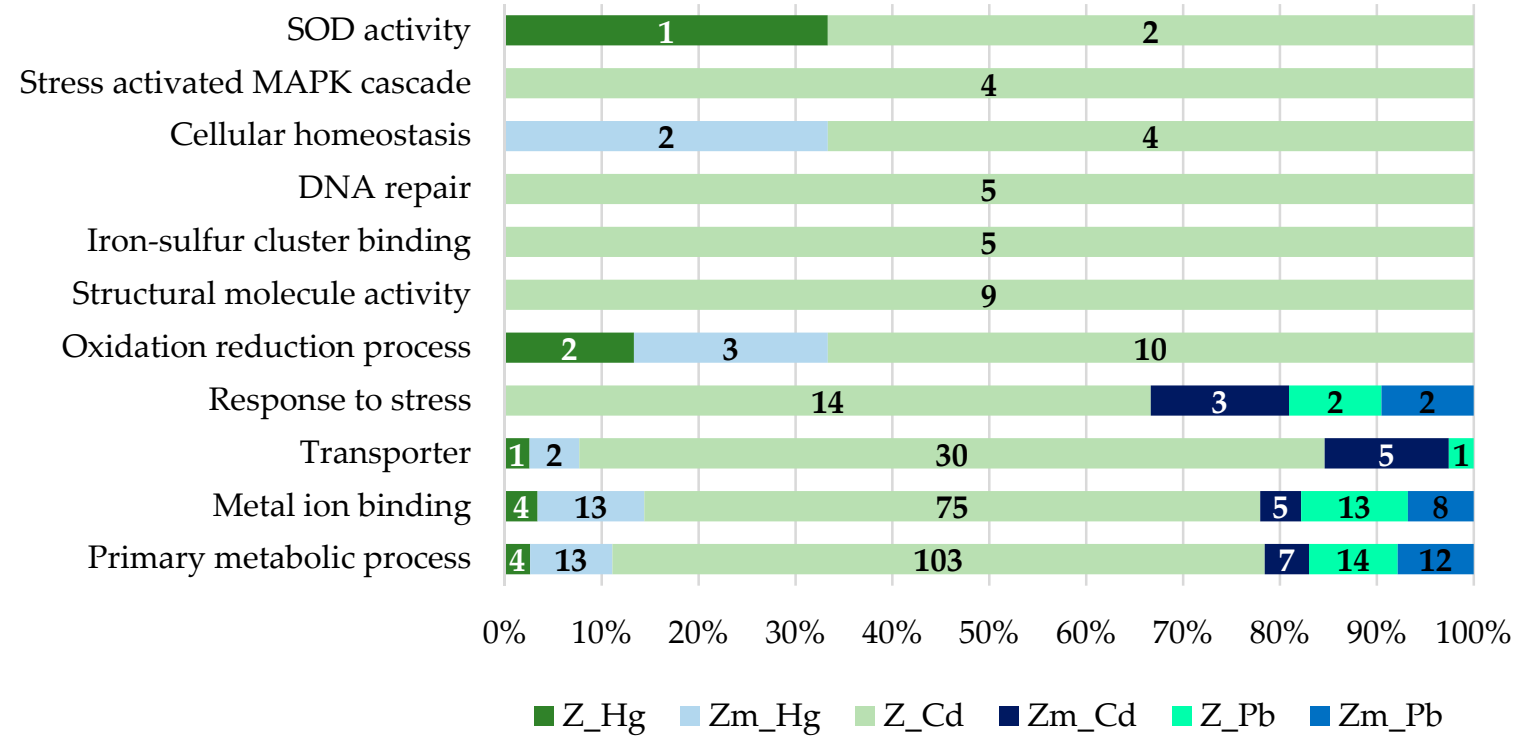

Figure 8. GO annotation of the proteins increased in abundance (fold change $\pm 1.5, p<0.05$ ) in E. gracilis $\mathrm{Z}$ - and $\mathrm{Zm}$ - strains treated with the heavy metals $\mathrm{Cd}, \mathrm{Hg}$, and $\mathrm{Pb}$. The proteins were categorized into different sets and denoted by bars specified with numbers (normalized to the total number).

The proteins increased in abundance, which may have a role in heavy metal bioaccumulation were categorized into different sets. The proteins increased in abundance in the Zm-strain are listed in Supplementary Table S2 and the data of proteins increased in abundance in the Z-strain was sourced from our previous study [28]. The analysis showed that during the $\mathrm{Hg}$ treatment, the number of proteins involved in the primary metabolic processes was lower in the Z-strain compared to the Zm-strain. Heavy metal ions can disrupt the primary metabolic function in several ways such as by damaging organelles or by replacing the essential metals in metalloproteins, particularly those that carry out enzymatic reactions. A drastic change in the proteome profile of the Z-strain treated with Cd compared to the Zm-strain was observed (Figure 8). This provides further evidence that the chloroplasts in E. gracilis assist to develop high tolerance against $\mathrm{Cd}$ and may have a proper mechanism to accumulate $\mathrm{Cd}$.

The induction of metal ion binding proteins occurs in conjunction with various metals and the active inducers are $\mathrm{Cd}, \mathrm{Zn}, \mathrm{Pb}$, silver (Ag) and antimony (Sb) [44]. In our study, the metal-binding proteins were highly abundant in the $\mathrm{Z}$-strain during $\mathrm{Cd}$ exposure. $\mathrm{Hg}$ and $\mathrm{Pb}$ exposure resulted in very few changes in the abundance of metal-binding proteins in both strains. Metal-binding proteins have specific binding abilities to different metals depending on the organism and strain. For instance, the $\mathrm{Zm}$-strain lacks chloroplasts and its ability to bind and accumulate $\mathrm{Cd}$ was lower compared to the Z-strain. In addition, the Zm-strain had more specificity for $\mathrm{Hg}$ than $\mathrm{Cd}$. Metal-binding proteins also play an important role in the intracellular trafficking of metal ions. Metal-binding proteins such as glutathione synthetase, second enzyme in the glutathione (GSH) biosynthesis pathway, was increased by 14 -fold in the Cd-treated Z-strain but not in the $\mathrm{Hg}$ and Pb-treated cells (Supplementary Table S3). Glutathione is crucial for heavy metal chelation and subsequent bioaccumulation in intracellular organelles. The number of several transition metal ion binding proteins was significantly enhanced during Cd treatment of the Z-strain. The increase in the GSH during Cd treatment in the chloroplast 
containing strain indicates the cellular ability to accumulate them in the chloroplast as shown by TEM studies (Figure 5e) and sequester them to non-toxic form.

Damage on DNA caused by heavy metals includes breaks in the double-stranded molecules as well as leads to inhibition of some of the critical proteins of the DNA repair pathway [45]. The level of DNA damage depends on the toxicity of the respective heavy metal and its concentration. Most importantly, the cellular ability to initiate the response towards DNA repair and the choice of construction or repair pathway determine the cellular ability to accumulate heavy metals [45]. In our study, five proteins responsible for initiating DNA repair were highly abundant in only the chloroplast containing Z-strain during $\mathrm{Cd}$ treatment compared to none in the non-chloroplast $\mathrm{Zm}$-strain (Figure 8). This may indicate the ability of the chloroplast containing strain to bioaccumulate and sequester $\mathrm{Cd}$ to protect against DNA damage.

\subsubsection{Transporters}

Transporters have a significant role in metal homeostasis. There were approximately five times more transporter proteins of which relative abundance was increased during heavy metal treatments in the Z-strain than in the Zm-strain (Table 2) and most of the changes in their abundance in the $\mathrm{Z}$-strain were caused by $\mathrm{Cd}$ treatment. Various heavy metal transporters have been characterized in plants $[46,47]$ and yeast $[48,49]$ and green alga Chlamydomonas $[14,50]$. The highly abundant transporters in the chloroplast and non-chloroplast containing strains were different except the ABC transporter. Transporters in the $\mathrm{Zm}$-strain may have a role in the intracellular trafficking of heavy metals and in the absence of chloroplasts, the most likely destination of heavy metal deposition would be either the mitochondria or cytosol. Two transporters were higher in abundance during $\mathrm{Hg}$ treatment of the Zm-strain (Table 2), including the copper-transporting ATPase RAN1. Copper-ATPases are crucial for maintaining metal homeostasis [51]. A transmembrane transporter multidrug resistance-associated protein member 2 (MRP2) was increased by 11.82-fold in the Zm-strain. MRP2 is involved in the transport of heavy metal conjugates into cellular organelles from the cytosol via ATP-dependent export pumps [52]. This transporter may be involved in $\mathrm{Hg}$ transport from the cytosol to mitochondria in the $\mathrm{Zm}$-strain. Moreover, the ABC transporter $\mathrm{G}$ family member 36, which has been characterized as a probable efflux pump of heavy metal ions [53], was also higher in abundance in the Cd treated $\mathrm{Zm}$-strain. Overexpression of this transporter has made plants more resistant to heavy metals [53]. The $\mathrm{Zm}$-strain may thus have also used this transporter to efflux the $\mathrm{Cd}$ and $\mathrm{Pb}$ out of the cells. 
Table 2. The highly abundant transporters $(\mathrm{FC}>2)$ during the $\mathrm{Cd}, \mathrm{Hg}$, and $\mathrm{Pb}$ treatments in E. gracilis Z- and Zm-strains.

\begin{tabular}{cccc}
\hline UniProt ID & Transporter & Heavy Metal & Fold Change \\
\hline & Zm-strain & & \\
F1DB26 & Multidrug resistance-associated protein_2 & $\mathrm{Hg}$ & 11.82 \\
A0A2R5GHD4 & Copper-transporting ATPase RAN1 & $\mathrm{Hg}$ & 7.59 \\
Q9XIE2 & ABC transporter G family member 36 & $\mathrm{Cd}$ & 4.52 \\
D0P1Q1 & Transmembrane transporter & $\mathrm{Cd}$ & 2.02 \\
& Z-strain & & 5.61 \\
D7LF89 & Heavy metal transporter MTP2 & $\mathrm{Cd}$ & 4.41 \\
Q9XIE2 & ABC transporter G family member 36 & $\mathrm{Hg}$ & $3.64 / 2.45$ \\
Q8H384 & Cadmium/zinc-transporting ATPase & $\mathrm{Cd} / \mathrm{Pb}$ & 3.60 \\
A0A1F3CY04 & Copper-translocating P-type ATPase & $\mathrm{Cd}$ & 3.46 \\
D7FUC2 & Ion transmembrane transporter activity & $\mathrm{Cd}$ & 3.36 \\
A0A1A0FLX3 & Potassium transporter TrkA & $\mathrm{Cd}$ & 3.25 \\
W2ZAX1 & Cation-transporting ATPase activity & $\mathrm{Cd}$ & 2.95 \\
K8EBM6 & Proton-transporting ATP synthase activity & $\mathrm{Cd}$ & 2.87 \\
A0A1E4SU43 & Mitochondrial carrier family & $\mathrm{Cd}$ & 2.80 \\
Q6BZ66 & Transmembrane transporter & $\mathrm{Cd}$ & 2.73 \\
A0A140AY28 & Sodium/potassium-transporting ATPase & $\mathrm{Cd}$ & 2.62 \\
K4ENZ7 & Calcium-transporting ATPase & $\mathrm{Cd}$ & 2.50 \\
A0A261XUE4 & Cation-transporting ATPase activity & $\mathrm{Cd}$ & 2.41 \\
Q9XIE2 & ABC transporter G family member 36 & $\mathrm{Hg}$ & 2.34 \\
V4AGW4 & Extracellular ligand-gated ion channel & $\mathrm{Cd}$ & 2.28 \\
E6Y2N7 & ATP: ADP antiporter activity & $\mathrm{Cd}$ & 2.26 \\
E1B2R7 & ATP-binding cassette sub-family & $\mathrm{Cd}$ & 2.20 \\
Q9XIE2 & ABC transporter G family member 36 & $\mathrm{Cd}$ & 2.00 \\
Q4DK78 & V-type proton ATPase subunit a & $\mathrm{Cd}$ & \\
\hline
\end{tabular}

In the Z-strain, the abundance of transporter proteins was most increased after Cd-treatment compared to other heavy metals whereas in the $\mathrm{Zm}$-strain $\mathrm{Hg}$ brought the highest increase in the abundance of transporter proteins (Figure 8; Table 2). The increase in abundance of different types and numbers of transporter proteins in the two strains highlights the difference in the molecular mechanism of chloroplast and non-chloroplast strains to tolerate or accumulate various heavy metals. Transporters that play a role in intracellular metal transportation were found to be highly abundant in the Z-strain. The cation diffusion facilitator (CDF) family of transporters are well known to chelate the heavy metals and sequester them to cellular organelles like the vacuole [54]. In chloroplast-containing plants, CDFs are known as Metal Tolerance Proteins (MTPs) because of their role in the sequestration of excessive $\mathrm{Zn}$ in the vacuoles [55]. MTP2, which was previously characterized as a transporter that has a role in Zn hyperaccumulation in Arabidopsis halleri and Noccaea caerulescens [55], was found to be highly abundant, by 3.61-fold increase, in the Z-strain (Table 2). Since E. gracilis lacks a plant-like proper vacuolar structure, the MTP2 transporter in the Z-strain may be involved in Cd sequestration into the chloroplasts, although the functional characterization of this transporter has not been performed yet. The increase in abundance of a P-type ATPase was 3.6-fold in the Z-strain. P-type ATPases are also known as heavy metal ATPases (HMAs) that are associated with the transport of heavy metals in plants [56] and yeast [57]. P-type ATPase are localized to the vacuolar membrane and helps in detoxification of $\mathrm{Zn}$ and $\mathrm{Cd}$ through vacuolar sequestration in yeast [58]. In Arabidopsis thaliana P-type ATPase are localized to the chloroplasts and assist in Zn detoxification [59]. The increase in abundance of the $\mathrm{ABC}$ transporter $\mathrm{G}$ family member 36 was 4.41 -fold (Table 2) in the Z-strain treated with $\mathrm{Hg}$; the Z-strain may have used this transporter to efflux the toxic $\mathrm{Hg}$ out of the cell similar to the probable efflux of $\mathrm{Cd}$ used by the $\mathrm{Zm}$-strain above. Overall, the transporter study indicated that chloroplasts have a role in bioaccumulation of $\mathrm{Cd}$ and efflux of $\mathrm{Hg}$ in the Z-strain. Although the $\mathrm{Zm}$-strain lacks chloroplasts it showed an excellent capacity to bioaccumulate $\mathrm{Hg}$ suggesting a role for the transporters in $\mathrm{Hg}$ accumulation and efflux of $\mathrm{Cd}$. 


\subsubsection{Chloroplast Proteins}

A few chloroplast proteins were high in abundance in the Z-strain treated with $\mathrm{Cd}$, while $\mathrm{Hg}$ and $\mathrm{Pb}$ did not bring about any significant changes in the chloroplast proteins. The Light-harvesting chlorophyll a/b binding protein (LHCB) was increased by 15.35-fold in the Z-strain (Table 3). LHCB expression operates a special mechanism in plants to modulate chloroplast stomatal movement against cellular stress caused by external stimuli such as exposure to heavy metals and drought; overall, LHCB functions to maintain plant fitness $[60,61]$. Cd is a strong inhibitor of photosynthesis and interrupts the electron transport chain in photosystem I (PSI) and photosystem II (PSII) [62]. The increase in expression of LHCB may help to better deal with the Cd toxicity and cope with the cellular stress brought by it. The level of $\mathrm{Cd}$ toxicity and cellular ability to resist it varies among different organisms. In our study, major changes in the abundance of chloroplast related proteins were seen in the Cd-treated Z-strain. As none of these proteins showed similar levels of changes during the other metal exposures, chloroplast related proteins may be specifically helping the Z-strain to withstand the toxicity of Cd.

Table 3. The chloroplast related proteins increased in abundance in the Z-strain treated with Cd.

\begin{tabular}{lll}
\hline Entry & Protein Name & Fold Change \\
\hline Q39725 & Light-harvesting chlorophyll a /b binding protein of PSII & 15.35 \\
A4QPI2 & Chloroplast light-harvesting complex II protein & 8.17 \\
A8HPC6 & Chloroplast light-harvesting complex I protein & 6.63 \\
P12356 & Photosystem I reaction center subunit III & 5.99 \\
A0A061RZ43 & Proton gradient regulation 5 & 4.47 \\
Q8GZR2 & Cytochrome f, chloroplastic & 4.28 \\
A8JH60 & Predicted protein chloroplastic & 2.92 \\
Q06SJ8 & Photosystem I assembly protein Ycf3 & 2.84 \\
A8IRG9 & Predicted protein chloroplastic & 1.81 \\
\hline
\end{tabular}

\section{Conclusions}

E. gracilis chloroplasts were found to have a role in assisting the accumulation of the heavy metal $\mathrm{Cd}$, whereas the other two metals tested, $\mathrm{Hg}$ and $\mathrm{Pb}$, were mostly deposited in the cytosol of both strains studied. Some deposition of $\mathrm{Hg}$ was also seen in the mitochondria. This, together with the proteomic data, indicates that the strains with $(\mathrm{Z})$ and without chloroplasts $(\mathrm{Zm})$ have different abilities and mechanisms to respond to the heavy metal exposure, especially concerning $\mathrm{Cd}$ and $\mathrm{Hg}$. Major changes in the abundance of chloroplast related proteins were seen in the Cd-treated Z-strain including light-harvesting chlorophyll a /b binding protein of PSII, indicating that the chloroplast related proteins may be specifically helping the Z-strain to withstand the toxicity of Cd. Exposure to $\mathrm{Hg}$ caused disturbance in the cell integrity, especially in the chloroplasts; however, $\mathrm{Cd}$ and $\mathrm{Pb}$ exposure did not bring about significant changes in cellular structure. While we focused on protein transporters and chloroplast-associated proteins, further analysis of all identified proteins will add to the current knowledge on the molecular mechanism operating in the tolerance and accumulation of heavy metals in E. gracilis. Considering the current data and the fact that E. gracilis has an innate tolerance to relatively high concentrations of heavy metals as demonstrated by the MICs obtained, the organism has the potential for the management of particular heavy metal contaminations of the environment.

Supplementary Materials: The following are available online at http://www.mdpi.com/2076-2607/8/1/115/s1, Figure S1: E. gracilis Z- and Zm- strains cultured in the GNY-medium only. Cells were collected each day until day 7. Error bars represent the standard deviation calculated from biological triplicates. The difference in the growth rate observed between the strains were not significantly different $(p>0.05)$. Table S1: Common differentially abundant proteins in the E. gracilis Z- and $\mathrm{Zm}$ - strains treated with heavy metals $\mathrm{Cd}, \mathrm{Hg}$ and $\mathrm{Pb}$. Table S2: The high abundance proteins in $E$. gracilis $\mathrm{Zm}$-strain during exposure to the heavy metals $\mathrm{Cd}, \mathrm{Pb}$ and $\mathrm{Hg}$. Table S3: The high abundance metal binding proteins $(\mathrm{FC}>1.5)$ in the E. gracilis Z- and Zm- strains treated with heavy metals.

Author Contributions: Conceptualization, B.K., A.S. (Angela Sun), A.S. (Anwar Sunna), H.N.; methodology and experimental design, B.K.; data collection, B.K., M.T.H., K.S.K.; data analysis, B.K.; writing-original draft 
preparation, B.K.; writing-review and editing, B.K., A.S. (Angela Sun), A.S. (Anwar Sunna), M.T.H., K.S.K., M.M., H.N.; supervision, H.N., A.S. (Angela Sun), A.S. (Anwar Sunna). All authors have read and agreed to the published version of the manuscript.

Funding: B.K. is supported by an international Macquarie University Research Excellence Scholarship (iMQRES).

Acknowledgments: We would like to thank Phuc Tran, Technical Team Manager at Macquarie University for guidance in operating the MP-AES. We would also like to thank Arthur Chien and Chao Shen from the Microscopy Unit, Macquarie University for guidance in TEM operation and sample preparation.

Conflicts of Interest: The authors declare no conflict of interest.

\section{References}

1. Järup, L. Hazards of heavy metal contamination. Br. Med. 2003, 68, 167-182. [CrossRef] [PubMed]

2. Johri, N.; Jacquillet, G.; Unwin, R. Heavy metal poisoning: The effects of cadmium on the kidney. Biometals 2010, 23, 783-792. [CrossRef] [PubMed]

3. Juang, R.-S.; Lin, L.-C. Treatment of complexed copper (II) solutions with electrochemical membrane processes. Water Res. 2000, 34, 43-50. [CrossRef]

4. Pulford, I.; Riddell-Black, D.; Stewart, C. Heavy metal uptake by willow clones from sewage sludge-treated soil: The potential for phytoremediation. Int. J. Phytoremediation 2002, 4, 59-72. [CrossRef]

5. Yoon, J.M.; Oliver, D.J.; Shanks, J.V. Phytotoxicity and phytoremediation of 2, 6-dinitrotoluene using a model plant, Arabidopsis thaliana. Chemosphere 2007, 68, 1050-1057. [CrossRef]

6. Schat, H.; Llugany, M.; Vooijs, R.; Hartley-Whitaker, J.; Bleeker, P.M. The role of phytochelatins in constitutive and adaptive heavy metal tolerances in hyperaccumulator and non-hyperaccumulator metallophytes. J. Exp. Bot. 2002, 53, 2381-2392. [CrossRef]

7. Hasan, M.K.; Cheng, Y.; Kanwar, M.K.; Chu, X.-Y.; Ahammed, G.J.; Qi, Z.-Y. Responses of Plant Proteins to Heavy Metal Stress-A Review. Front. Plant Sci. 2017, 8, 1492. [CrossRef]

8. Luo, Z.-B.; Wu, C.; Zhang, C.; Li, H.; Lipka, U.; Polle, A. The role of ectomycorrhizas in heavy metal stress tolerance of host plants. Environ. Exp. Bot. 2014, 108, 47-62. [CrossRef]

9. Mishra, S.; Dubey, R. Heavy metal uptake and detoxification mechanisms in plants. Int. J. Agric. 2006, 1, 122-141.

10. Kneer, R.; Kutchan, T.M.; Hochberger, A.; Zenk, M.H. Saccharomyces cerevisiae and Neurospora crassa contain heavy metal sequestering phytochelatin. Arch. Microbiol. 1992, 157, 305-310. [CrossRef]

11. Mühlenhoff, U.; Stadler, J.A.; Richhardt, N.; Seubert, A.; Eickhorst, T.; Schweyen, R.J.; Lill, R.; Wiesenberger, G. A specific role of the yeast mitochondrial carriers MRS3/4p in mitochondrial iron acquisition under iron-limiting conditions. J. Biol. Chem. 2003, 278, 40612-40620. [CrossRef] [PubMed]

12. Bashir, K.; Ishimaru, Y.; Shimo, H.; Nagasaka, S.; Fujimoto, M.; Takanashi, H.; Tsutsumi, N.; An, G.; Nakanishi, H.; Nishizawa, N.K. The rice mitochondrial iron transporter is essential for plant growth. Nat. Commun. 2011, 2, 322. [CrossRef] [PubMed]

13. Nouet, C.; Motte, P.; Hanikenne, M. Chloroplastic and mitochondrial metal homeostasis. Trends Plant Sci. 2011, 16, 395-404. [CrossRef] [PubMed]

14. Blaby-Haas, C.E.; Merchant, S.S. The ins and outs of algal metal transport. BBA-Mol. Cell Res. 2012, 1823, 1531-1552. [CrossRef] [PubMed]

15. Belyaeva, E.A.; Dymkowska, D.; Więckowski, M.R.; Wojtczak, L. Mitochondria as an important target in heavy metal toxicity in rat hepatoma AS-30D cells. Toxicol. Appl. Pharmacol. 2008, 231, 34-42. [CrossRef] [PubMed]

16. Ranjbar, A.; Ghasemi, H.; Rostampour, F. The role of oxidative stress in metals toxicity; mitochondrial dysfunction as a key player. Galen Med. J. 2014, 3, 2-13.

17. Shcolnick, S.; Keren, N. Metal homeostasis in cyanobacteria and chloroplasts. Balancing benefits and risks to the photosynthetic apparatus. Plant Physiol. 2006, 141, 805-810. [CrossRef]

18. Marchetti, C. Role of calcium channels in heavy metal toxicity. ISRN Toxicol. 2013, 2013. [CrossRef]

19. Nies, A.T.; Keppler, D. The apical conjugate efflux pump ABCC2 (MRP2). Pflugers Arch 2007, 453, $643-659$. [CrossRef]

20. Hanikenne, M. Chlamydomonas reinhardtii as a eukaryotic photosynthetic model for studies of heavy metal homeostasis and tolerance. New Phytol. 2003, 159, 331-340. [CrossRef] 
21. Shamshad, I.; Khan, S.; Waqas, M.; Asma, M.; Nawab, J.; Gul, N.; Raiz, A.; Li, G. Heavy metal uptake capacity of fresh water algae (Oedogonium westti) from aqueous solution: A mesocosm research. Int. J. Phytoremediation 2016, 18, 393-398. [CrossRef]

22. Yu, Q.; Matheickal, J.T.; Yin, P.; Kaewsarn, P. Heavy metal uptake capacities of common marine macro algal biomass. Water Res. 1999, 33, 1534-1537. [CrossRef]

23. Pawlik-Skowrońska, B. Resistance, accumulation and allocation of zinc in two ecotypes of the green alga Stigeoclonium tenue Kütz. coming from habitats of different heavy metal concentrations. Aquat Bot. 2003, 75, 189-198. [CrossRef]

24. Devars, S.; Hernandez, R.; Moreno-Sánchez, R. Enhanced heavy metal tolerance in two strains of photosynthetic Euglena gracilis by preexposure to mercury or cadmium. Arch. Environ. Contam. Toxicol. 1998, 34, 128-135. [CrossRef]

25. Moreno-Sánchez, R.; Rodríguez-Enríquez, S.; Jasso-Chávez, R.; Saavedra, E.; García-García, J.D. Biochemistry and Physiology of Heavy Metal Resistance and Accumulation in Euglena. In Euglena: Biochemistry, Cell and Molecular Biology; Schwartzbach, S.D., Shigeoka, S., Eds.; Springer International Publishing: Cham, Switzerland, 2017; pp. 91-121.

26. Mendoza-Cózatl, D.G.; Moreno-Sánchez, R. Cd ${ }^{2+}$ transport and storage in the chloroplast of Euglena gracilis. Biochim. Biophys. Acta 2005, 1706, 88-97. [CrossRef]

27. Einicker-Lamas, M.; Mezian, G.A.; Fernandes, T.B.; Silva, F.L.; Guerra, F.; Miranda, K.; Attias, M.; Oliveira, M.M. Euglena gracilis as a model for the study of $\mathrm{Cu}^{2+}$ and $\mathrm{Zn}^{2+}$ toxicity and accumulation in eukaryotic cells. Environ. Pollut. 2002, 120, 779-786. [CrossRef]

28. Khatiwada, B.; Hasan, M.T.; Sun, A.; Kamath, K.S.; Mirzaei, M.; Sunna, A.; Nevalainen, H. Proteomic response of Euglena gracilis to heavy metal exposure-Identification of key proteins involved in heavy metal tolerance and accumulation. Algal Res. 2020, 45, 101764. [CrossRef]

29. Rodríguez-Zavala, J.; Ortiz-Cruz, M.; Mendoza-Hernández, G.; Moreno-Sánchez, R. Increased synthesis of $\alpha$-tocopherol, paramylon and tyrosine by Euglena gracilis under conditions of high biomass production. J. Appl. Microbiol. 2010, 109, 2160-2172. [CrossRef]

30. Ebringer, L.; Mego, J.; Jurášek, A.; Kada, R. The action of streptomycins on the chloroplast system of Euglena gracilis. Microbiology 1969, 59, 203-209. [CrossRef]

31. Ben-Shaul, Y.; Ophir, I. Effects of streptomycin on plastids in dividing Euglena. Planta 1970, 91, $195-203$. [CrossRef]

32. Shanab, S.; Essa, A.; Shalaby, E. Bioremoval capacity of three heavy metals by some microalgae species (Egyptian Isolates). Plant. Signal. Behav. 2012, 7, 392-399. [CrossRef]

33. Esmaeili, A.; Saremnia, B.; Kalantari, M. Removal of mercury (II) from aqueous solutions by biosorption on the biomass of Sargassum glaucescens and Gracilaria corticata. Arab. J. Chem. 2015, 8, 506-511. [CrossRef]

34. Lysenko, E.A.; Klaus, A.A.; Pshybytko, N.L.; Kusnetsov, V.V. Cadmium accumulation in chloroplasts and its impact on chloroplastic processes in barley and maize. Photosynth. Res. 2015, 125, 291-303. [CrossRef]

35. Hakmaoui, A.; Ater, M.; Boka, K.; Baron, M. Copper and cadmium tolerance, uptake and effect on chloroplast ultrastructure. Studies on Salix purpurea and Phragmites australis. Z. Naturforsch. C 2007, 62, 417-426. [CrossRef]

36. Lee, H.-Y.; Back, K. Cadmium disrupts subcellular organelles, including chloroplasts, resulting in melatonin induction in plants. Molecules 2017, 22, 1791. [CrossRef]

37. Weigel, H.J. Inhibition of Photosynthetic Reactions of Isolated Intact Chloroplasts by Cadmium. J. Plant. Physiol 1985, 119, 179-189. [CrossRef]

38. Zhou, J.; Zhang, Z.; Zhang, Y.; Wei, Y.; Jiang, Z. Effects of lead stress on the growth, physiology, and cellular structure of privet seedlings. PLoS ONE 2018, 13, e0191139. [CrossRef]

39. Sheoran, I.; Singh, R. Effect of heavy metals on photosynthesis in higher plants. In Photosynthesis: Photoreactions to Plant Productivity; Abrol, Y.P., Mohanty, P., Govindjee, Eds.; Springer: Berlin/Heidelberg, Germany, 1993; pp. 451-468.

40. Heumann, H.G. Effects of heavy metals on growth and ultrastructure of Chara vulgaris. Protoplasma 1987, 136, 37-48. [CrossRef]

41. Mendoza-Cózatl, D.G.; Rodríguez-Zavala, J.S.; Rodríguez-Enríquez, S.; Mendoza-Hernandez, G.; Briones-Gallardo, R.; Moreno-Sánchez, R. Phytochelatin-cadmium-sulfide high-molecular-mass complexes of Euglena gracilis. FEBS J. 2006, 273, 5703-5713. [CrossRef] 
42. Zakrys, B.; Cambra-Sanchez, J.; Walne, P.L. Chloroplast ultrastructure of Euglena cuneata Pringsheim, E. deses Ehrenberg and E. mutabilis (Euglenophyceae): Taxonomic significance. Acta. Protozool. 2001, 40, 161-167.

43. Mortimer, D.C.; Czuba, M. Structural damage to leaf chloroplasts of Elodea densa caused by methylmercury accumulated from water. Ecotoxicol. Environ. Saf. 1982, 6, 193-195. [CrossRef]

44. Narender Reddy, G.; Prasad, M.N.V. Heavy metal-binding proteins/peptides: Occurrence, structure, synthesis and functions. A review. Environ. Exp. Bot. 1990, 30, 251-264. [CrossRef]

45. Morales, M.E.; Derbes, R.S.; Ade, C.M.; Ortego, J.C.; Stark, J.; Deininger, P.L.; Roy-Engel, A.M. Heavy metal exposure influences double strand break DNA repair outcomes. PLoS ONE 2016, 11, e0151367. [CrossRef]

46. Williams, L.E.; Pittman, J.K.; Hall, J. Emerging mechanisms for heavy metal transport in plants. Biochim. Biophys. Acta-Biomembranes 2000, 1465, 104-126. [CrossRef]

47. Mäser, P.; Thomine, S.; Schroeder, J.I.; Ward, J.M.; Hirschi, K.; Sze, H.; Talke, I.N.; Amtmann, A.; Maathuis, F.J.; Sanders, D. Phylogenetic relationships within cation transporter families of Arabidopsis. Plant. Physiol. 2001, 126, 1646-1667. [CrossRef]

48. Ortiz, D.; Kreppel, L.; Speiser, D.; Scheel, G.; McDonald, G.; Ow, D. Heavy metal tolerance in the fission yeast requires an ATP-binding cassette-type vacuolar membrane transporter. EMBO J. 1992, 11, 3491-3499. [CrossRef]

49. Diffels, J.F.; Seret, M.L.; Goffeau, A.; Baret, P.V. Heavy metal transporters in Hemiascomycete yeasts. Biochimie 2006, 88, 1639-1649. [CrossRef]

50. Arunakumara, K.K.I.U.; Zhang, X. Heavy metal bioaccumulation and toxicity with special reference to microalgae. J. Ocean. U. China 2008, 7, 60-64. [CrossRef]

51. Prohaska, J.R. Role of copper transporters in copper homeostasis. Am. J. Clin. Nutr. 2008, 88, 826S-829S. [CrossRef]

52. Homolya, L.; Varadi, A.; Sarkadi, B. Multidrug resistance-associated proteins: Export pumps for conjugates with glutathione, glucuronate or sulfate. BioFactors 2003, 17, 103-114. [CrossRef]

53. Kim, D.Y.; Bovet, L.; Maeshima, M.; Martinoia, E.; Lee, Y. The ABC transporter AtPDR8 is a cadmium extrusion pump conferring heavy metal resistance. Plant J. 2007, 50, 207-218. [CrossRef]

54. Kolaj-Robin, O.; Russell, D.; Hayes, K.A.; Pembroke, J.T.; Soulimane, T. Cation Diffusion Facilitator family: Structure and function. FEBS Lett. 2015, 589, 1283-1295. [CrossRef] [PubMed]

55. Ricachenevsky, F.; Menguer, P.; Sperotto, R.; Williams, L.; Fett, J. Roles of plant metal tolerance proteins (MTP) in metal storage and potential use in biofortification strategies. Front. Plant. Sci. 2013, 4, 144. [CrossRef] [PubMed]

56. Takahashi, R.; Bashir, K.; Ishimaru, Y.; Nishizawa, N.K.; Nakanishi, H. The role of heavy-metal ATPases, HMAs, in zinc and cadmium transport in rice. Plant Signal. Behav. 2012, 7, 1605-1607. [CrossRef]

57. Adle, D.J.; Lee, J. Expressional control of a cadmium-transporting P1B-type ATPase by a metal sensing degradation signal. J. Biol. Chem. 2008, 283, 31460-31468. [CrossRef]

58. Gravot, A.; Lieutaud, A.; Verret, F.; Auroy, P.; Vavasseur, A.; Richaud, P. AtHMA3, a plant P1B-ATPase, functions as a $\mathrm{Cd} / \mathrm{Pb}$ transporter in yeast. FEBS Lett. 2004, 561, 22-28. [CrossRef]

59. Kim, Y.Y.; Choi, H.; Segami, S.; Cho, H.T.; Martinoia, E.; Maeshima, M.; Lee, Y. AtHMA1 contributes to the detoxification of excess $\mathrm{Zn}(\mathrm{II})$ in Arabidopsis. Plant J. 2009, 58, 737-753. [CrossRef]

60. Xu, Y.-H.; Liu, R.; Yan, L.; Liu, Z.-Q.; Jiang, S.-C.; Shen, Y.-Y.; Wang, X.-F.; Zhang, D.-P. Light-harvesting chlorophyll a/b-binding proteins are required for stomatal response to abscisic acid in Arabidopsis. J. Exp. Bot. 2011, 63, 1095-1106. [CrossRef]

61. Ganeteg, U.; Külheim, C.; Andersson, J.; Jansson, S. Is each light-harvesting complex protein important for plant fitness? Plant Physiol. 2004, 134, 502-509. [CrossRef]

62. Mallick, N.; Mohn, F. Use of chlorophyll fluorescence in metal-stress research: A case study with the green microalga Scenedesmus. Ecotoxicol. Environ. Saf. 2003, 55, 64-69. [CrossRef]

(C) 2020 by the authors. Licensee MDPI, Basel, Switzerland. This article is an open access article distributed under the terms and conditions of the Creative Commons Attribution (CC BY) license (http://creativecommons.org/licenses/by/4.0/). 